\title{
Solar Water Heating Systems Applied to High-Rise Buildings-Lessons from Experiences in China
}

\author{
Junpeng Huang ${ }^{1} \mathbb{D}$, Jianhua Fan ${ }^{1, * \mathbb{D}}$, Simon Furbo ${ }^{1}$ and Liqun $\mathrm{Li}^{2}$ \\ 1 Department of Civil Engineering, Technical University of Denmark, 2800 Copenhagen, Denmark \\ 2 Shanghai Sanxiang impression co., Ltd., Shanghai 200434, China \\ * Correspondence: jif@byg.dtu.dk
}

Received: 16 June 2019; Accepted: 5 August 2019; Published: 9 August 2019

check for updates

\begin{abstract}
High-rise buildings have a significant impact on the surrounding environment. Building-integrated solar water heating $(\mathrm{SWH})$ systems are effective ways to use renewable energy in buildings. Impediments, such as security concerns, aesthetics and functionality, make it difficult to apply SWH systems in high-rise buildings. At present, only China uses SWH systems on a large scale in such buildings. What are China's experiences and lessons learned in applying SWH systems in high-rises? Are these experiences scalable to other countries? This study used a combination of field investigation, literature review and case study to summarize 36 systems that had been in operation for 1-14 years. System types, collector types, installation methods, types of auxiliary heat sources, economic performance and various basic principles were summarized. The economic performance of SWH systems in high-rise buildings was analyzed and verified by a case study in Shanghai. The results show that the installation of SWH systems in high-rise buildings is feasible and reliable. Individual household systems (61\%) were more popular than centralized systems $(25 \%)$ and hybrid systems account (14\%). The average area of solar collectors per household was $2.17 \mathrm{~m}^{2} /$ household, the average design solar fraction was $52 \%$. Flat plate solar collectors $(53 \%)$ was the most commonly used collector, while electric heating elements $(89 \%)$ were the most common auxiliary heat sources for SWH systems, followed by gas water heaters and air source heat pumps. The cost of SWH systems per $\mathrm{m}^{2}$ of a building area was between $22 \mathrm{CNY} / \mathrm{m}^{2}$ to $75 \mathrm{CNY} / \mathrm{m}^{2}$. China's unique practical experience gives a reference for other countries in their efforts to make high-rise buildings more sustainable.
\end{abstract}

Keywords: Solar water heating system; high-rise building; building-integrated solar thermal; solar fraction; levelized cost of heat

\section{Introduction}

Solar thermal heating systems are utilized in millions of residences worldwide [1] and have made a great contribution to the sustainable development of the earth [2]. Solar water heaters are not only widely used in rural China [3] but also in rural areas in Australia [4], Turkey [5], India [6], and parts of Africa [7]. However, it is more urgent for urban buildings to improve energy efficiency and reduce emissions [8]. Building-integrated solar thermal systems are effective ways to use renewable energy in buildings [9]. Since urban buildings are located in areas with high population and development density, the occlusion between buildings is severe. The space required for the installation of solar collectors is often lacking [10].

Despite the challenges, experts from countries and regions such as China [11-13], Germany [9], Greece [14], Netherlands [15], Israel [16], Argentina [17], Korea [18], Hong Kong [19-21], Iran [22,23], Brazil [16,24], Turkey [25] and Vietnam [26], are still actively exploring the potential for and possible technical solutions to apply solar water heating (SWH) systems in urban buildings. In China, the application of solar hot water in urban buildings has received considerable support from the 
government [27]. Since 2007, in order to increase energy efficiency in buildings and promote the application of renewable energy therein, under the guidance of national and local building energy conservation codes, 23 provinces and three municipalities issued mandatory installation policies for SWH systems in buildings with less than 12 floors (some provinces and municipalities required six floors). The implementation of this policy resulted in dramatic changes, with the market share of SWH in the urban domestic hot water market reaching $24 \%$ [28] over the past ten years.

Increases in urbanization and technological advancement have led to buildings of ever-increasing height. High-rise buildings have a significant impact on the surrounding environment [29], and their shadows significantly reduce the possibility of applying solar energy for surrounding low-rise buildings. However, high-rise buildings can accrue substantial benefits from exposure to more solar radiation. Does this mean that $\mathrm{SWH}$ systems are feasible in high-rise buildings? Is this especially true in terms of technical and economic performance?

Over the past few years, there has been a plethora of research and reviews on low-rise buildings and building-integrated solar thermal (BIST) systems for small buildings, especially low rises [9,30-36]. For buildings with a height of 35-100 meters or 12-33 floors, previous studies focused on policy recommendations [37-39], or case studies [40,41], but there has been no comprehensive systematic summary of the safety, economic performance, aesthetics and technical solutions of SWH systems.

By utilizing an investigation of existing high-rise buildings using SWH systems in China, the experience and lessons learned from SWH system application in high-rise buildings will be summarized in this study. The technical solutions and economic performance of SWH systems will be systematically analyzed with a case study in Shanghai.

Solar hot water has great potential in urban buildings [42]. The technical recommendations based on the research presented in this paper will not only help improve the energy efficiency of high-rise buildings and reduce the energy cost for urban residents but also help governments around the world to achieve renewable energy application goals, promote technological innovations, increase employment and improve people's livelihoods in developing countries.

\section{Methodology}

A literature review, deep interviews, a questionnaire survey and field investigation were carried out in this study. From 2016 to 2018, government officials, real estate developers, designers, solar water heater manufacturers, property management personnel and users were interviewed. A total of 36 SWH systems in high-rise buildings were investigated on-site; 200 questionnaires were distributed to the stakeholders and the valid and effective samples numbered 156 . There were 26 questions in the questionnaire that covered the whole process of design, construction, commissioning, operation and maintenance of solar hot water systems in high-rise buildings, including solar fraction determination, hot water usage, system types, collector types, installation method and common malfunction.

The systems were randomly selected from 21 cities nationwide, from Beijing in the north to Shenzhen in the south, as shown in Figure 1. The 36 SWH systems in high-rises were built from 2005 to 2018 with a height from 35 to 100 meters. The average height of the buildings is 62 meters with 21 floors; Figure 2 shows the distribution of the height of the buildings by years; the dotted line in Figure 2 shows that there is a trend toward taller buildings over the past 14 years. 


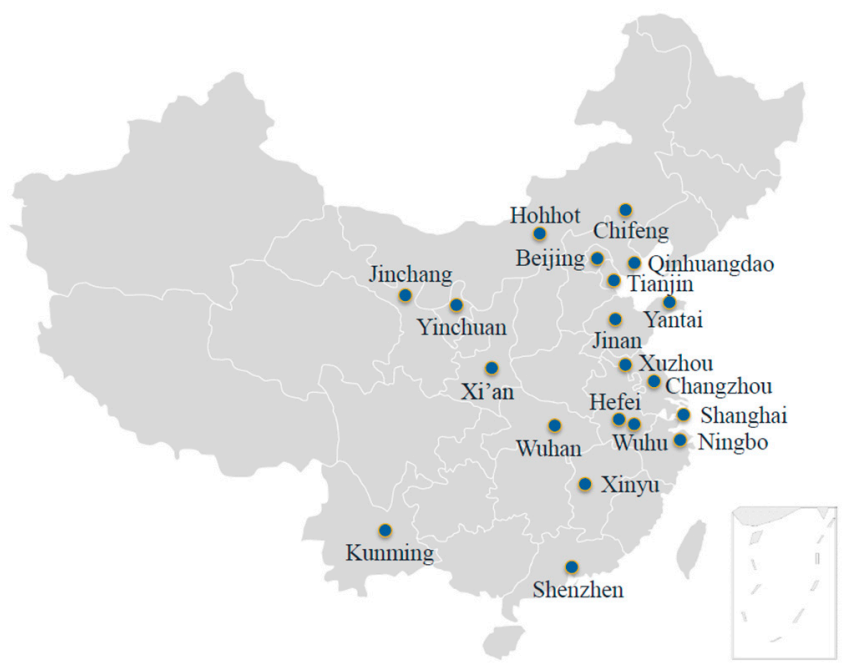

Figure 1. Geographical distribution of surveyed projects.

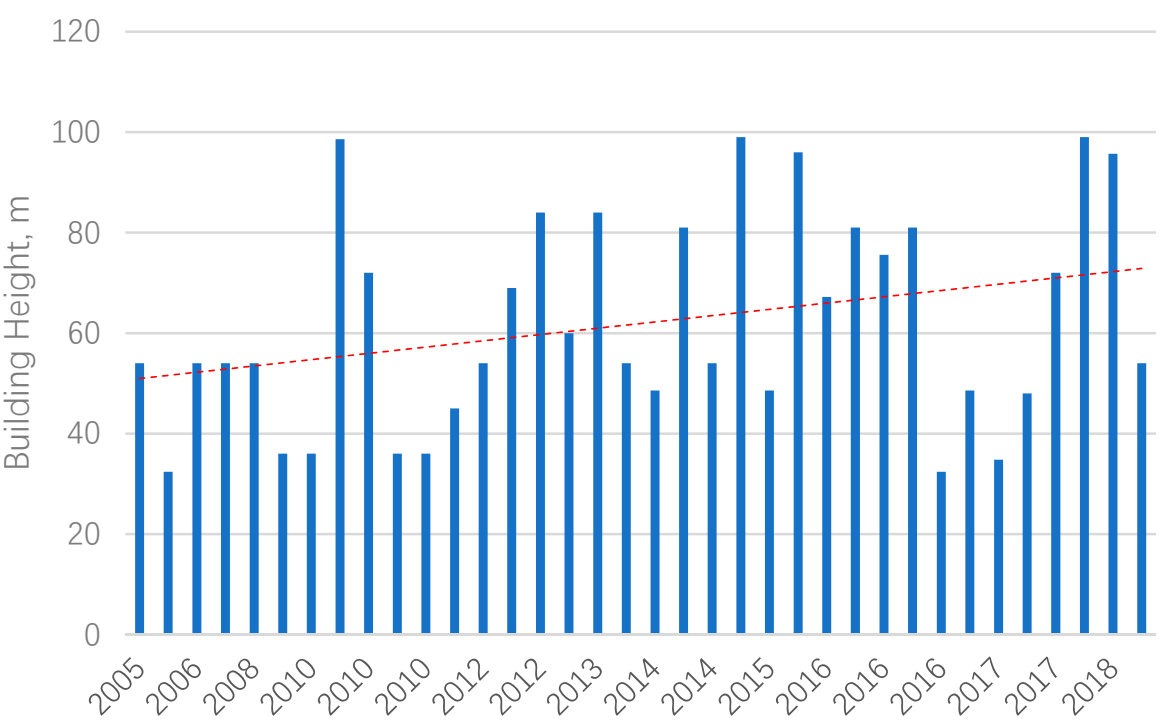

Figure 2. The height of the investigated high-rise buildings by year completed.

Theoretical calculations and field measurements of a household SWH system in a high-rise residential building in Shanghai were conducted. The index of levelized cost of heat (LCoH) recommended by International Energy Agency (IEA) Task 54 [43] was used to evaluate its economic performance.

The measurement method is based on the Evaluation Standard for Application of Renewable Energy in Buildings (Chinese standard GB/T 50801-2013) [44]. The measured parameters include ambient temperature, wind speed, aperture area of a solar collector, solar radiation on the plane of the solar collector, water volume in the water tank and water temperature in the water tank. Equations (1)-(4) are used to calculate the solar fraction of a solar water heating system.

$$
Q_{z}=\sum_{i=1}^{n} m_{z i} \rho_{w} C_{w}\left(t_{d z i}-t_{b z i}\right) \Delta T_{z i} \times 10^{-6}
$$

$Q_{z}$ is the total energy consumption of the solar water heating system in MJ; $\mathrm{n}$ is the total number of records; $m_{z i}$ is the hot water flow rate recorded in i-th test in $\mathrm{m}^{3} / \mathrm{s} ; \rho_{w}$ is the density of hot water in $\mathrm{kg} / \mathrm{m}^{3} ; c_{w}$ is the specific heat capacity of water in $\mathrm{J} /(\mathrm{kg} \cdot \mathrm{K}) ; t_{d z i}$ is the hot water temperature recorded in 
i-th test in ${ }^{\circ} \mathrm{C} ; t_{b z i}$ is the cold water temperature recorded in i-th test in ${ }^{\circ} \mathrm{C} ; \Delta T_{z i}$ is the time step in $\mathrm{s}$, in this case, $\Delta T_{z i}=10 \mathrm{~s}$.

$$
Q_{s}=\sum_{i=1}^{n} m_{s i} \rho_{s w} C_{s w}\left(t_{d s i}-t_{b s i}\right) \Delta T_{s i} \times 10^{-6}
$$

$Q_{s}$ is the total heat gain of solar collectors in MJ; $m_{s i}$ is the working fluid flow rate in the heat collection system recorded in i-th test in $\mathrm{m}^{3} / \mathrm{s} ; \rho_{s w}$ is the density of collector fluid in $\mathrm{kg} / \mathrm{m}^{3} ; c_{s w}$ is the specific heat capacity of a collector fluid in $\mathrm{J} /(\mathrm{kg} \cdot \mathrm{K}) ; t_{d s i}$ is the collector fluid temperature at the outlet recorded in i-th test in ${ }^{\circ} \mathrm{C}$; $t_{b s i}$ is the collector fluid temperature at the inlet recorded in i-th test in ${ }^{\circ} \mathrm{C}$; $\Delta T_{s i}$ is the time step in $\mathrm{s}$, in this case, $\Delta T_{s i}=10 \mathrm{~s}$.

$$
f_{j}=\frac{Q_{s}}{Q_{z}}
$$

$f_{j}$ is the solar fraction obtained in short-term tests under specific solar radiation conditions in $\%$.

$$
f=\frac{x_{1} f_{1}+x_{2} f_{2}+x_{3} f_{3}+x_{4} f_{4}}{x_{1}+x_{2}+x_{3}+x_{4}}
$$

$f$ is the calculated annual solar fraction of the system in $\% ; x_{1}$ is the number of days when local solar radiation is less than $8 \mathrm{MJ} / \mathrm{m}^{2} ; x_{2}$ is the number of days when local solar radiation is equal to or higher than $8 \mathrm{MJ} / \mathrm{m}^{2}$, but less than $13 \mathrm{MJ} / \mathrm{m}^{2} ; x_{3}$ is the number of days when local solar radiation is equal to or higher than $13 \mathrm{MJ} / \mathrm{m}^{2}$, but less than $18 \mathrm{MJ} / \mathrm{m}^{2} ; x_{4}$ is the number of days when local solar radiation is higher than $18 \mathrm{MJ} / \mathrm{m}^{2} ; f_{1}$ is the $\mathrm{SF}$ when local solar radiation is less than $8 \mathrm{MJ} / \mathrm{m}^{2}$ in $\%$; $f_{2}$ is the SF when local solar radiation is equal to or higher than $13 \mathrm{MJ} / \mathrm{m}^{2}$, but less than $18 \mathrm{MJ} / \mathrm{m}^{2} \mathrm{in} \%$; $f_{3}$ is the SF when local solar radiation is equal to or higher than $13 \mathrm{MJ} / \mathrm{m}^{2}$, but less than $18 \mathrm{MJ} / \mathrm{m}^{2}$ in $\% ; f_{4}$ is the SF when local solar radiation is higher than $18 \mathrm{MJ} / \mathrm{m}^{2}$ in $\%$. The measurement variables, equipment and accuracy are listed in Table 1:

Table 1. The measurement variables, equipment and accuracy for the case study.

\begin{tabular}{clc}
\hline Measured Variables & Equipment & Accuracy \\
\hline Ambient air temperature & Thermometer & $\pm 0.1 \mathrm{~K}$ \\
\hline Wind speed & Anemometer & $\pm 0.1 \mathrm{~m} / \mathrm{s}$ \\
\hline Solar radiation & Pyranometer & $\pm 10 \%$ \\
\hline Water temperature & 4 -wire PT100 & $\pm 0.5 \mathrm{~K}$ \\
\hline Collector fluid temperature & 4-wire PT100 & $\pm 0.5 \mathrm{~K}$ \\
\hline The total water flow rate in the water heating system & Flowmeter & $\pm 1 \%$ \\
\hline The collector fluid flow rate in the solar collector & Flowmeter & $\pm 1 \%$ \\
\hline
\end{tabular}

\section{Results}

\subsection{Three Basic Principles}

It is a challenge for both architects and manufacturers to apply SWH systems in high-rise buildings so that they provide highly efficient domestic hot water solutions, and simultaneously ensure the safety and reliability of the systems. Three principles are suggested as prerequisites of BIST installations, namely, aesthetics, solar thermal performance and solar-control requirements [9], as well as three basic building requirements, namely, that they are functional, constructive and formal [44]. However, for SWH systems in high-rises, safety is the most important, followed by aesthetics and functionality. 
(1). Safety

Over the past 14 years, none of the investigated 36 systems experienced collectors falling from their edifices, showing that applying SWH systems in high-rises is safe. Table 2 shows the types of SWH systems commonly used in high-rise buildings. The safety hazards of these systems are mainly manifested in water leakage, short-circuiting, collapse and lightning strikes during use. Such accidents involving safety in SWH systems mostly occur in areas of severe cold. The most common of these is water leakage caused by vacuum tube explosion, fire in the insulation layer caused by inferior quality electric heating rods, and formation of ice on roofs caused by water leakage.

The weight of solar collectors adds an additional load to the building structure, however. The average weight of a compound parabolic collector with a U-shaped copper pipe inside (CPC) or a flat plate collector (FPC) is approximately $20 \mathrm{~kg} / \mathrm{m}^{2}$ while operating with water or other working fluid inside, but an all-glass evacuated tubular collector (AGETC) weighs about $50 \mathrm{~kg} / \mathrm{m}^{2}$. Table 3 lists the weight of different types of solar collectors commonly used in high-rise residential buildings. The safety issue must be addressed by improving the load capacity of building components, and reserving appropriate installation space and maintenance space for solar collectors on the external walls of buildings. In order to prevent strong winds from separating solar collectors from their fixtures, wind load must also be considered in the design of connecting fasteners, including the depth and strength of these fasteners, taking into consideration the most adverse climatic conditions. In terms of safety, the collector type of choice is FPCs and they are the most commonly used collectors in high-rise residential buildings.

\section{(2). Aesthetics}

In addition to being safe, solar collectors must satisfy requirements for architectural aesthetics. These requirements are summarized by IEA Task 41 Solar Energy and Architecture for aesthetic quality of buildings integrated solar collectors [45], including natural integration, architecturally pleasing design, aesthetic composition of colors and materials, size that suits the harmony and combination of the structure, consistency with the context of the building, and well composed and innovative design.

In order to receive sunlight, solar collectors must be placed outdoors. For the individual household SWH systems commonly used in high-rise buildings, collectors are usually installed only on the exterior walls or balcony railings. The installation of collectors will destroy the original design style of the building facade. That is why SWH systems are often considered to be troublesome by architects. The successful implementation of SWH systems in high-rise buildings requires designer involvement in the integrated design process from the planning and design stage of the project [46-48]. Carefully integrated design of solar thermal components and building envelopes enables limited improvement in the overall energy performance of the buildings, including an increase in energy generation potential from SWH systems and the reduction of cooling loads. To achieve these objectives, architects should fully understand the material characteristics and the safety requirements of the collector products, and integrate collectors as one of the performance elements of the architectural style in the facade design of the building.

\section{(3). Functionality}

A total of $86 \%$ of the investigated residents expressed satisfaction with the results of SWH systems. Only a few households located on the ground floor or severely obstructed by adjacent buildings reflected that the SWH system could not produce enough hot water and the electricity consumption was too large. The problems reported by the survey users include: insufficient hot water in winter $(29 \%)$, water leakage $(21 \%)$, unstable water temperature $(10 \%)$, excessive power consumption of circulating water pumps $(7 \%)$, and overheating in summer $(5 \%)$. 
Table 2. Types of solar water heating (SWH) systems commonly used in high-rise buildings.

System Type

System schematic

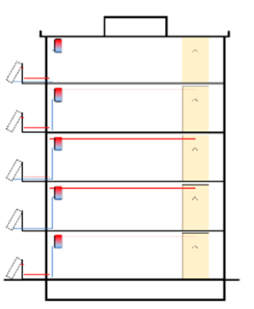

Central System

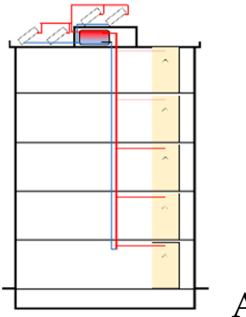

Hybrid System

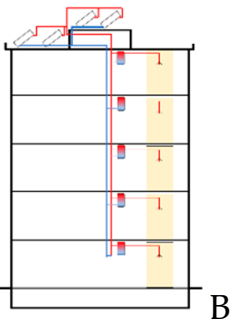

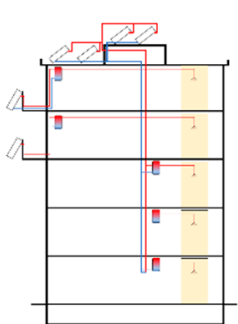

Solar collectors are centrally installed on the roof,

the heat obtained by the solar collector is stored in

a central water tank which supplies hot water to

households (A). Alternatively, absent a central

water tank, heat obtained by the solar collector is stored in individual water tanks by heat exchangers inside in households (B). individually. The heat obtained by the solar

heat exchangers inside in households.
Some collectors are installed centrally on the roof and partially on balconies or walls between windows. This is a hybrid of an individual household system and a central system.

\begin{tabular}{ccc}
\hline Collector area & $1.5-3.0 \mathrm{~m}^{2} /$ household & $0.67-3.9 \mathrm{~m}^{2} /$ household \\
\hline Advantages & $\begin{array}{c}\text { Property rights are clear, the system is simple, the } \\
\text { performance is stable, and the control is flexible. }\end{array}$ & $\begin{array}{c}\text { The collectors are installed on the roof, which does } \\
\text { not affect the appearance of the building. The } \\
\text { system has a high collection efficiency. }\end{array}$ \\
\hline
\end{tabular}


Table 2. Cont

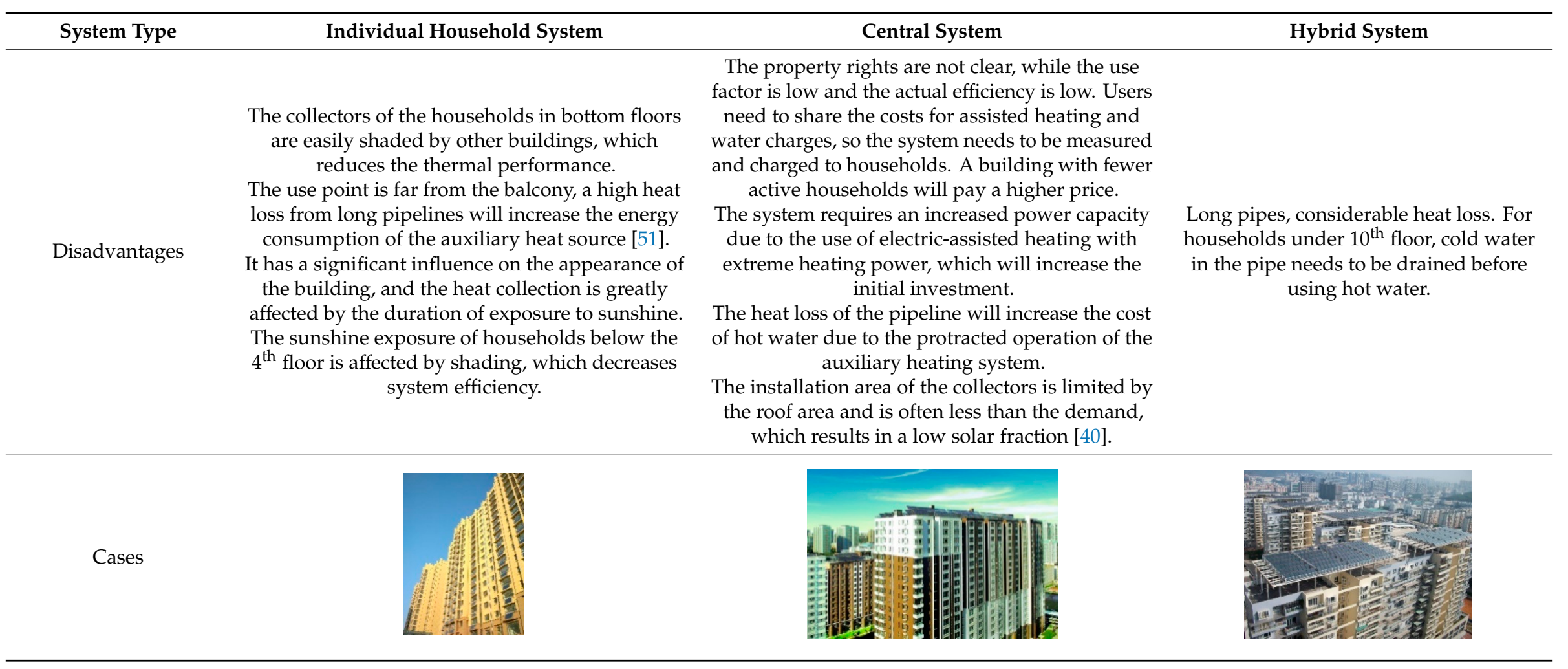


Table 3. A technical and economic comparison of solar collectors commonly used in high-rise buildings.

\begin{tabular}{|c|c|c|c|c|c|}
\hline & FPC & HPETC & $\mathrm{CPC}$ & UPETC & AGETC \\
\hline \multicolumn{6}{|l|}{ Pictures of collectors } \\
\hline $\begin{array}{l}\text { Coefficient of } \\
\text { performance }\end{array}$ & $\begin{array}{c}\kappa \theta=1, \eta_{0}=0.799 \\
a_{1}=2.41, a_{2}=0.015\end{array}$ & $\begin{array}{c}\kappa \theta=1, \eta_{0}=0.618 \\
\mathrm{a}_{1}=1.38, \mathrm{a}_{2}=0.018\end{array}$ & $\begin{array}{c}\kappa \theta=1, \eta_{0}=0.632 \\
a_{1}=0.338, a_{2}=0.011\end{array}$ & $\begin{array}{c}\kappa \theta=1, \eta_{0}=0.632 \\
a_{1}=0.638, a_{2}=0.016\end{array}$ & $\begin{array}{c}\kappa \theta=1, \eta_{0}=0.636 \\
a_{1}=0.654, a_{2}=0.013\end{array}$ \\
\hline Aperture area & $2.88 \mathrm{~m}^{2}$ & $2.1 \mathrm{~m}^{2}$ & $2.1 \mathrm{~m}^{2}$ & $2.1 \mathrm{~m}^{2}$ & $2.1 \mathrm{~m}^{2}$ \\
\hline Temperature & $60-80^{\circ} \mathrm{C}$ & $60-120^{\circ} \mathrm{C}$ & $60-120^{\circ} \mathrm{C}$ & $60-120^{\circ} \mathrm{C}$ & $60-100{ }^{\circ} \mathrm{C}$ \\
\hline Weight* & $17.5 \mathrm{~kg} / \mathrm{m}^{2}$ & $23.1 \mathrm{~kg} / \mathrm{m}^{2}$ & $18.5 \mathrm{~kg} / \mathrm{m}^{2}$ & $22.0 \mathrm{~kg} / \mathrm{m}^{2}$ & $50 \mathrm{~kg} / \mathrm{m}^{2}$ \\
\hline Incremental cost ${ }^{* *}$ & $40 \mathrm{CNY} / \mathrm{m}^{2}$ & $55 \mathrm{CNY} / \mathrm{m}^{2}$ & $65 \mathrm{CNY} / \mathrm{m}^{2}$ & $57 \mathrm{CNY} / \mathrm{m}^{2}$ & $32 \mathrm{CNY} / \mathrm{m}^{2}$ \\
\hline Durability & $\begin{array}{l}\text { Strong weather durability } \\
\text { with a thicker tempered glass } \\
\text { cover. }\end{array}$ & $\begin{array}{c}\text { More susceptible to } \\
\text { breaking with thinner glass. }\end{array}$ & $\begin{array}{l}\text { The sealed silicone ring is } \\
\text { easy to age, causing the entire } \\
\text { tube to lose vacuum. }\end{array}$ & Same as HPETC and CPC & $\begin{array}{l}\text { Fragile and prone to more } \\
\text { maintenance. }\end{array}$ \\
\hline Installation & More walls, fewer roofs & More roofs, fewer walls & Walls and roofs & Walls and roofs & More roofs, fewer walls \\
\hline Disadvantages & Weak wind resistance & Difficulty for integration & Difficulty for integration & Difficulty for integration & Fragile \\
\hline
\end{tabular}

* The total weight of the collector in operation with a heat transfer medium; ** The incremental cost refers to the increase in building construction cost due to the installation of SWH systems. Incremental Cost $=\frac{\text { The cost of solar water heating system equipment+installation fees }}{\text { The building area served by the solar water heating system }}, \mathrm{CNY} / \mathrm{m}^{2}$ 
To ensure that SWH systems produce enough hot water, the solar collector surface should receive at least four hours of sunshine during the winter solstice [49]. For high-rise buildings, the ideal installation location to meet the sunshine requirement is on the rooftop of the building. However, because of high building density, roof areas often fail to meet the solar collector requirement for the hot water demand of all households. Therefore, it is not enough for high-rise buildings to provide domestic hot water to all users by installing solar collectors on roofs. Additional installation space is needed to improve the solar fraction of SWH system, e.g., on exterior walls, balconies and bay windows. The solar fraction (SF) is the fraction of the heating demand covered by solar energy. A higher solar fraction means a higher contribution of solar energy in a SWH system.

Although solar collectors can also be used as a sunshade component [50], if solar collectors are installed on a balcony or wall of a high-rise building, mutual shading between buildings, as well as shade covering collectors of residents on lower floors [50], will reduce the efficiency of the system and increase the energy consumption of auxiliary heat sources. Usually, the aperture area of the collector is half-blocked, and the energy consumption of the auxiliary heat source is correspondingly doubled [51].

\subsection{Hot Water Usage and Storage Tank Capacity}

Bathing with hot water has become a basic need for urbanites in China. Daily hot water consumption for this demographic is mainly used for bathing and cooking, among which bathing is the primary use; the peak of hot water consumption is from 19:00 to 23:00 in the evening and the water supply temperature is set between $42{ }^{\circ} \mathrm{C}$ and $53{ }^{\circ} \mathrm{C}$ [52]. Corresponding hot water consumption is between 31 and $47 \mathrm{~L}$ per person per day for different seasons and climates [53]. According to the Code for Design of Building Water Supply and Drainage (GB50015-2009) [54] and practical experience, the daily hot water usage of each household is assumed to be 100-150 L, which is determined by the size of the flat and the size of the family.

\subsection{System Types}

Although thermosiphon solar water heaters dominate the solar thermal market in China's rural areas, split pressure systems are the most commonly used solar water heating system for high-rise buildings. The types of SWH systems commonly used in high-rise buildings mainly include centralized systems, household systems and hybrid systems. High-rise buildings have a large number of users, high demand for hot water and a limited roof area. A centralized hot water system with collectors installed on a roof has a low solar fraction for each household. The massive heat loss caused by the long pipeline greatly reduces the economics of an SWH system. Qu Yan [55] has carried out calculations and statistics on the available area of the rooftops for SWH systems and the number of floors in dozens of high-rise residential buildings in Shanghai with different configurations (one ladder with two households, one ladder with three households and one ladder with four households). The results show that the available roof area of the layout for one ladder with two households can only install solar collectors to meet the hot water demand for users in 10-14 floors. The available roof area of the layout for one ladder with three households and four households can only install solar collectors to meet the hot water demand for users in 7 floors.

For household systems, the low-rise residents are affected by the occlusion of other buildings, and the actual heat gain of solar collectors is also low. Therefore, the system with the higher solar fraction is a hybrid combining centralized and household systems: household systems for high-rise households and centralized systems for low-rise households. However, the cost of a hybrid system is considerable.

Table 2 lists the common types of SWH systems used in high-rise residential buildings. In the 36 SWH systems, individual household systems account for $61 \%$, centralized systems account for $25 \%$, and hybrid systems account for $14 \%$.

The collector area per household is determined by the hot water demand and influenced by the installation location. The collector area per household for the household system is between $1.5 \mathrm{~m}^{2}$ and $3.0 \mathrm{~m}^{2}$. The collector area per household in centralized systems is closely related to the installation 
location and varies greatly. If the installation location is limited to the roof, the installation area is insufficient, and the minimum is only $0.67 \mathrm{~m}^{2}$ per household. If a roof is designed for the installation of the collectors as a floating board, the installation area can be expanded considerably. The collector area per household in high-rise buildings can exceed the household system, up to $3.9 \mathrm{~m}^{2}$. For hybrid systems, the collector area per household is between $1.4 \mathrm{~m}^{2}$ and $2.8 \mathrm{~m}^{2}$. In the 36 systems, the average area of solar collectors per household is $2.17 \mathrm{~m}^{2}$ /household, the average design SF is $52 \%$.

\subsection{Collector Types}

There are five types of solar collectors in use, of which, FPCs account for 53\% (19 systems), CPCs account for $14 \%$ ( 5 systems), evacuated tubular collectors with a U-shaped copper pipe inside (UPETC) account for $11 \%$ (4 systems), evacuated tubular collectors with a heat pipe inside (HPETC) account for $6 \%$ ( 2 systems), all-glass evacuated tubular solar collectors (AGETC) account for $17 \%$ (6 systems).

Heat collection efficiency is an essential performance indicator for solar collectors. The efficiency varies greatly for different incidence angles and different climates [56]. To compare the efficiency of different types of solar collectors used in high-rise buildings, the efficiency equations for each type of solar collectors are listed in Table 3. Efficiency equations were obtained from the Solar Keymark database for comparison with the same test standard (ISO 9806:2017) for different types of collectors. Equation (5) is the efficiency equation for solar collectors.

$$
\eta=\kappa \theta \cdot \eta_{0}-a_{1} \frac{T_{m}-T_{a}}{G}-a_{2} \frac{\left(T_{m}-T_{a}\right)^{2}}{G}
$$

where:

$\eta$ is the collector efficiency;

$\eta_{0}$ is the peak collector efficiency;

$\kappa \theta$ is the incidence angle modifier;

$\theta$ is the incidence angle for radiation in ${ }^{\circ}$;

$a_{1}$ is the heat loss coefficient of a collector at ambient temperature in $\mathrm{W} /\left(\mathrm{m}^{2} \mathrm{~K}\right)$;

$a_{2}$ is the temperature dependence of the heat loss coefficient of a collector in $\mathrm{W} /\left(\mathrm{m}^{2} \mathrm{~K}^{2}\right)$;

$T_{m}$ is the mean solar collector fluid temperature in ${ }^{\circ} \mathrm{C}$;

$T_{a}$ is the ambient temperature in ${ }^{\circ} \mathrm{C}$; and

$G$ is the solar irradiance on the collector in $\mathrm{W} / \mathrm{m}^{2}$.

For the collector efficiency, the heat production by the solar collector can be calculated with Equation (6).

$$
Q=A \cdot G \cdot \eta
$$

where:

$\mathrm{Q}$ is the power produced by the solar collector in $\mathrm{W}$; and

A is the gross area of the solar collector in $\mathrm{m}^{2}$.

In addition to the five collectors mentioned in this article, there are many types of solar collectors used in buildings, including photovoltaic thermal hybrid solar collectors (PV/T) collectors, unglazed FPCs and polymeric collectors [57-59]. For high-rise buildings, the choice of FPC is due to safety concerns. As shown in Table 3, the biggest advantage of FPCs over evacuated tubular collectors is ease of installation and higher safety. They are lighter, have no fragile glass, and the color of their surfaces can be modified. These features make it easier to integrate FPC with building façade design. Figure 3 shows some cases in which the vacuum tubes were broken during use. Visa et al. $[59,60]$ proposed shaped flat plate collector (FPC) assemblies to create/adapt different building facade styles. However, such products can only be customized in small quantities and are not scalable, resulting in high cost and little practical value. 


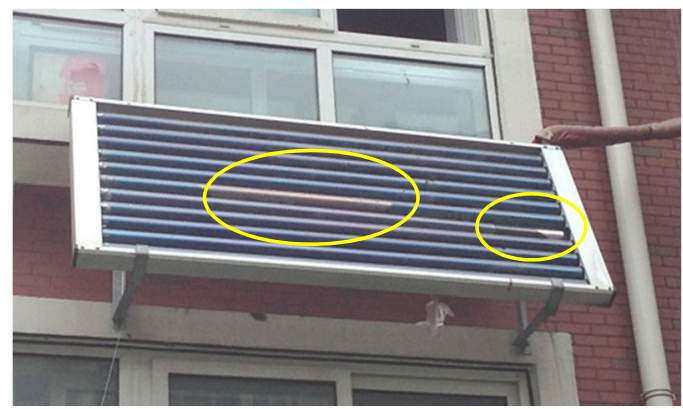

(a) Multiple broken vacuum tubes in an evacuated tubular collector with a U-shaped copper pipe inside (UPETC).

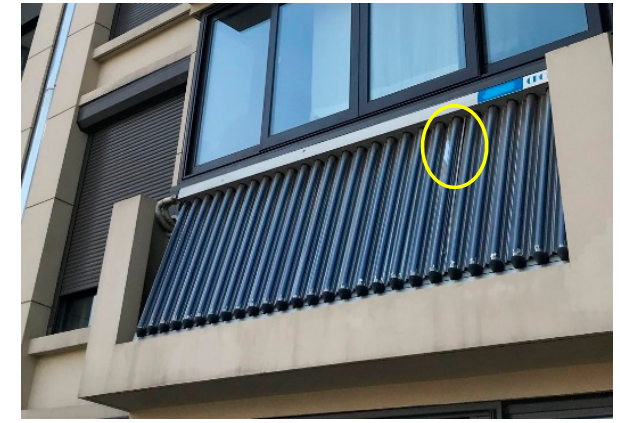

(b) One broken vacuum tube in a compound parabolic collector with a U-shaped copper pipe inside (CPC).

Figure 3. Broken vacuum tubes in evacuated tubular collectors.

\subsection{System Components}

Water tanks, pipelines and circulating water pumps are essential components of SWH systems. In this survey, many system components were also found to be used improperly.

(1) Water tank: Due to inappropriate construction and installation, many pressurized water tanks leak water during use, especially through the connection between the water tank and pipeline. Poor quality of the inner tank of the pressurized water tank and improper connection of the temperature probe to the inner tank can cause the inner tank to leak.

(2) Pipeline: $58 \%$ of the collectors are connected using polypropylene random copolymer (PPR) pipes. The greatest problems with PPR pipes are water leakage, poor insulation and rust, as shown in Figure 4.

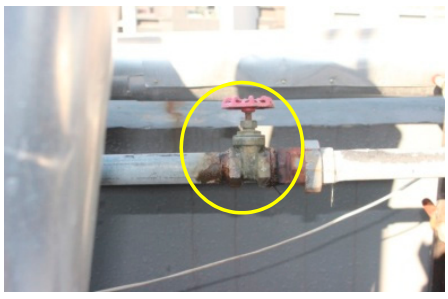

(a) Water leakage at the valve

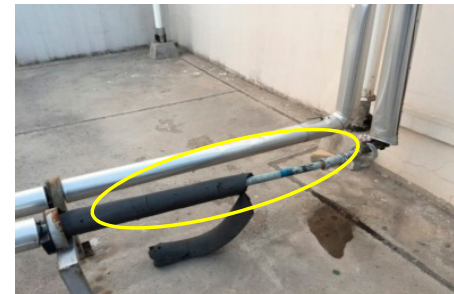

(b) Pipe insulation layer falling off

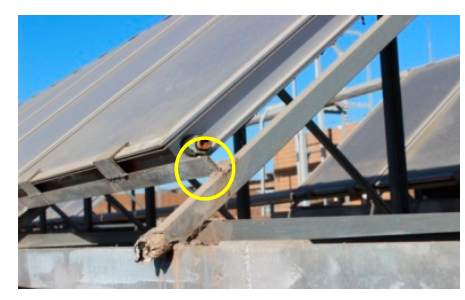

(c) The end nozzle is directly blocked, and scale is deposited.

Figure 4. Common problems with piping systems.

(3) Hot water circulation pump: Problems with rust, start and stop control failure, lack of a backup pump and no noise reduction mechanisms were observed, as shown in Figure 5. The noise problem caused by circulating water pumps is the most common complaint from residents on the top floor. 


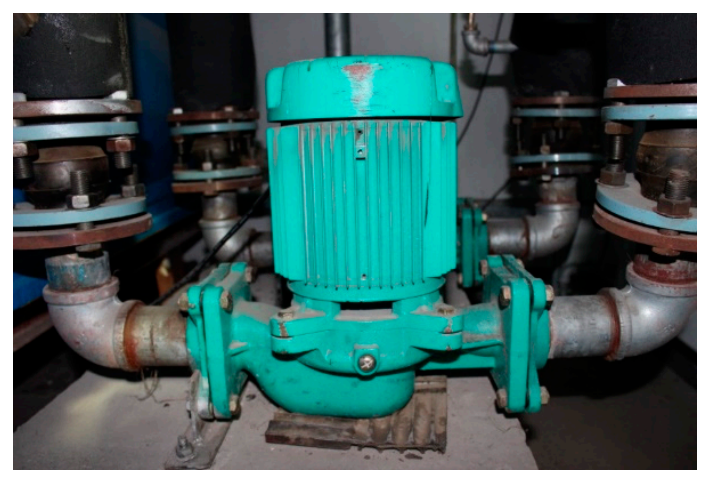

Figure 5. A circulating water pump without vibration reduction treatment.

\subsection{Installations}

\section{(1) Roofs}

Rooftops are the best place for the installation of solar collectors, with sufficient exposure to sunshine and less impact on building facade design. Table 4 shows three integration form factors of the collector on three different roof structures. To ensure adequate installation area and sunshine for solar collectors, Type 3, a floating board, is used to support the solar collectors. The floating board not only prevents the roof from being exposed to direct sunlight in summer, therefore reducing the cooling load of the rooms on the top floor, but also forms a housing platform while meeting both technical and landscape requirements [61].

Table 4. Solar collectors installation modes on roofs.

\begin{tabular}{|c|c|c|c|}
\hline Types & Type 1: Flat Roof & Type 2: Slope Roof & Type 3: Floating Board \\
\hline \multicolumn{4}{|l|}{ Sketches } \\
\hline Installation mode & Mounted on a bracket & Embedded roof & Mounted on a bracket \\
\hline Angle & Local latitude & Same as the slope of the roof & Local latitude \\
\hline Cases & $\frac{4}{y}$ & & 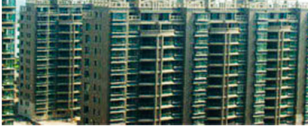 \\
\hline
\end{tabular}

Because high-rise buildings mainly have flat roofs, none of the investigated projects used the roof-mounted installations that are more common in Europe. Limited by installation area, the roof installation collector needs to avoid installation in a position of minimal efficacy and does not reserve enough maintenance space, as shown in Figure 6a,c. Leakage is a common problem in SWH systems, as shown in Figure 6b. If collectors are installed on the roof, additional waterproofing of the roof is required. 


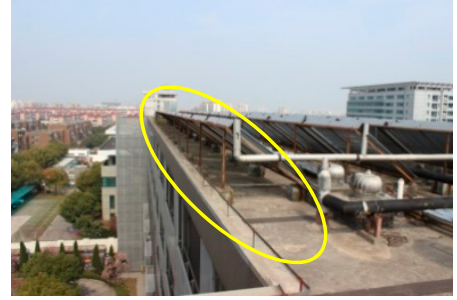

(a) No maintenance space

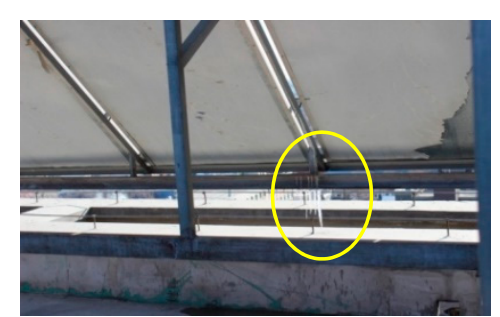

(b) Collector leaking water and freezing

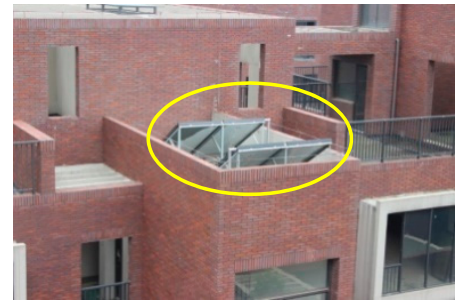

(c) Collector is blocked

Figure 6. Common problems when installing solar collectors on roofs.

(2) Walls

Wall-mounted installation includes both vertical and inclined configurations as shown in Table 5. In terms of safety and efficiency, Type 4 is best for high-rise buildings. There is a great security risk for Type 1 and Type 3 installation modes. Type 2 is not conducive to the maintenance of the collector.

Table 5. Solar collectors installation modes on walls.

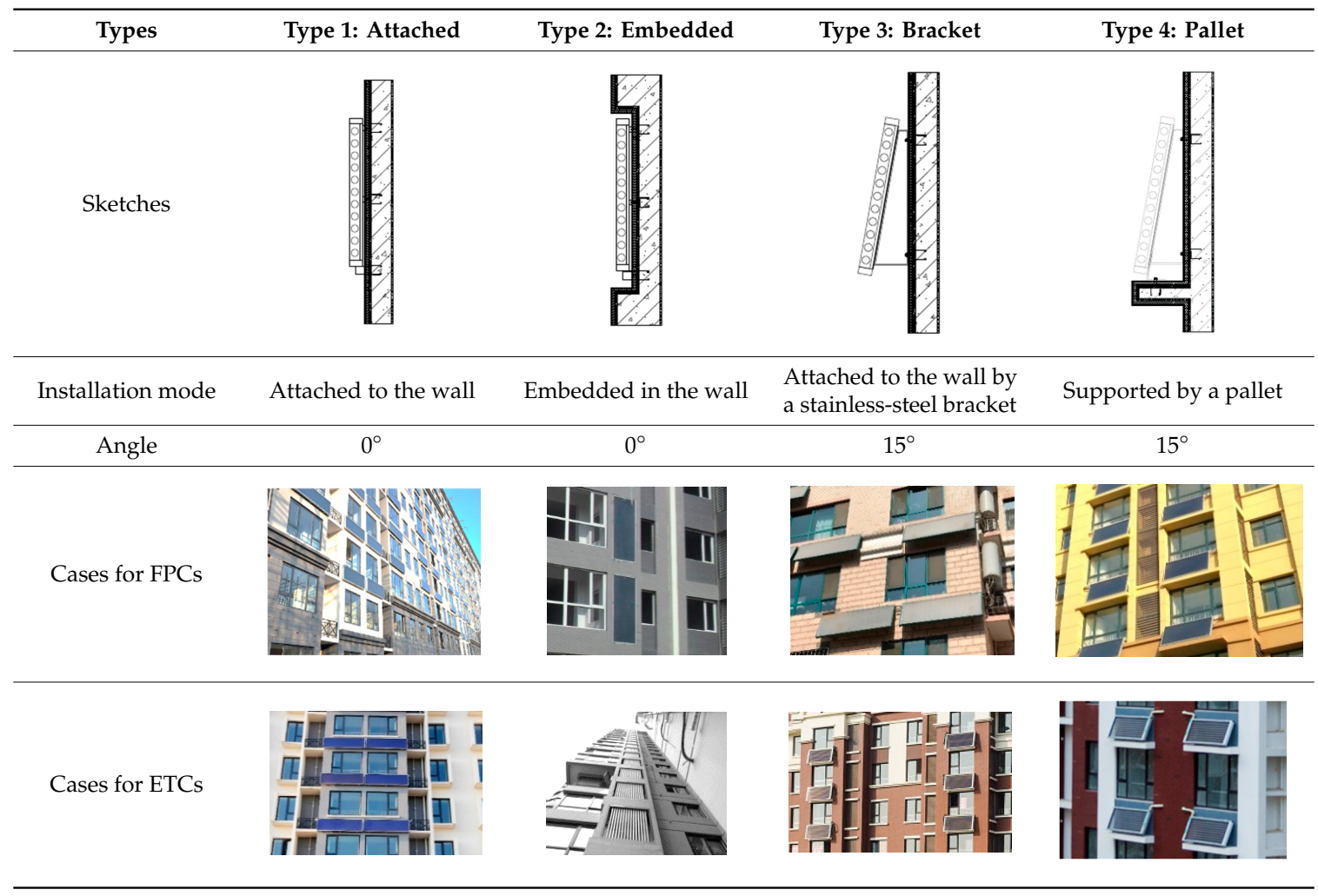

Collectors also can be used as a fixture to the outer facing windows, as shown in Figure 7 . This installation requires that the color of the glass is the same as the color of the absorber surface of the collector. 


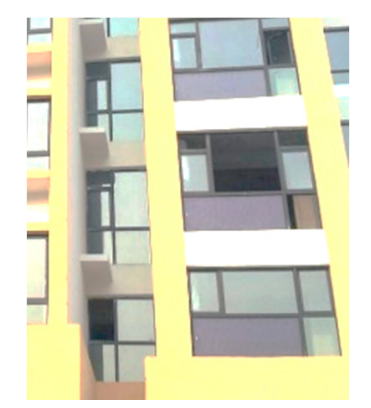

Figure 7. Collectors used as part of the outside windows.

For installation of solar collectors on walls, sufficient space should be guaranteed for ease of maintenance. The wrong installation method as shown in Figure 8a; once the collector fails, the parts cannot be replaced, eventually causing the equipment to lie idle. In order to save costs, the installation of Type 3 was widespread in China, which is an installation method containing significant security risks. If an uncertified stainless steel bracket is used or if a rivet is not driven to a sufficient depth in a wall, the collector would easily fall from a tall building, as shown in Figure 8b. At present, this type of installation has been gradually reduced, and Type 4 with a pre-designed platform has become popular.

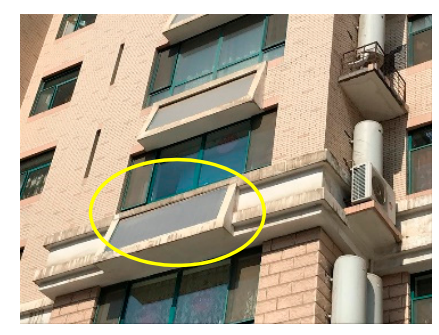

(a) No maintenance space.

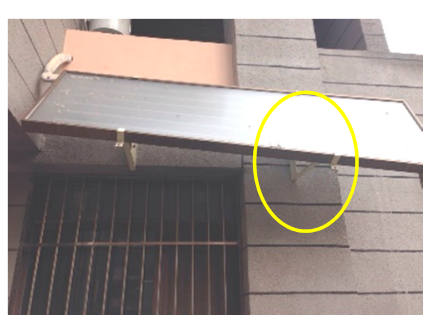

(b) Unqualified stainless-steel bracket rusts easily.

Figure 8. Common problems with wall-mounted installation.

(3) Balconies

Balcony-mounted installation also includes vertical and inclined configurations as shown in Table 6. There is a lower cost for vertical installation but these have lower system efficiency. The SWH system is more efficient while utilizing tilting installation, but it also requires higher material costs and careful design. A combination of collectors and railings is an excellent way to install solar collectors in high-rise buildings as shown in Type 1 of Table 6 . This installation mode not only does not occupy additional space, but the collector can also replace the original railing, decreasing a portion of the material cost without affecting the original façade design of the building. 
Table 6. Solar collector installation modes on balconies.

\begin{tabular}{|c|c|c|c|}
\hline Types & Type 1: Attached & Type 2: Bracket & Type 3: Pallet \\
\hline Sketches & & & \\
\hline Installation mode & $\begin{array}{l}\text { Integrated with balcony } \\
\text { railings }\end{array}$ & $\begin{array}{l}\text { Attached to balcony railings } \\
\text { by a stainless-steel bracket }\end{array}$ & $\begin{array}{l}\text { Attached and supported by a } \\
\text { pallet }\end{array}$ \\
\hline Angle & $0^{\circ}$ & $15^{\circ}$ & $15^{\circ}$ \\
\hline Cases & & & \\
\hline
\end{tabular}

\subsection{Auxiliary Heat Sources}

Electric heating elements are the most common auxiliary heat sources for SWH systems. Electric heating elements account for $89 \%$ (32 projects) of all cases. Gas water heaters (GWH) or gas boilers ( 3 projects) and air source heat pumps (ASHP) (1 project) are also used as auxiliary heat sources. A comprehensive comparison of different types of auxiliary heat sources in individual household SWH systems is shown in Table 7.

Table 7. A comparison of different types of auxiliary heat sources in individual household SWH systems.

\begin{tabular}{|c|c|c|c|}
\hline Heat Sources & Electric Heating Element & GWH or Gas Boiler & ASHP \\
\hline Efficiency & $70 \%$ & $90 \%-107 \%$ & $\mathrm{COP}^{*}, 2.5-3$ \\
\hline Cost/Household & 50-100 CNY & 2500-6000 CNY & $6000 \mathrm{CNY}$ \\
\hline Advantages & $\begin{array}{c}\text { Space saving, a low initial } \\
\text { investment }\end{array}$ & $\begin{array}{l}\text { Instant heat when using, } \\
\text { Low operating cost }\end{array}$ & Low operating cost \\
\hline Disadvantages & High operating cost & $\begin{array}{c}\text { The high initial } \\
\text { investment, } \\
\text { Needs installation space }\end{array}$ & $\begin{array}{c}\text { The high initial } \\
\text { investment, } \\
\text { Requires a large } \\
\text { installation space, noisy }\end{array}$ \\
\hline
\end{tabular}

* COP is an abbreviation of the coefficient of performance of a heat pump, which is a ratio of useful heating provided to work required.

From practical experience, compared with electric heating in hot water storage tanks, an "instant heat when using" GWH has a higher solar fraction and lower annual energy consumption. Liu Jian [62] conducted a test for a household SWH system in Shanghai with a $100 \mathrm{~m}^{2}$ building area for different auxiliary heat sources and found that the solar fraction was increased by $45.4 \%$, and the annual operating costs were reduced by $40.7 \%$ with a GWH compared to electric heating.

Due to the heat loss from water tanks, the auxiliary electric heating element consumes an abundance of energy to maintain constant water temperature in the water tank. This signifies that electric heating is inefficient. Although electric heating dominates the auxiliary heat source market for SWH systems at present, a GWH is recommended as the best choice for the auxiliary heat source for an 
SWH system if there is adequate installation space. This is especially true due to its high reliability, high cost-effectiveness and increased convenience.

\subsection{Economic Performance}

By analyzing the 36 cases in different cities in China, the cost of SWH systems per $\mathrm{m}^{2}$ of building area, including equipment expenses and the installation cost, is between $22 \mathrm{CNY} / \mathrm{m}^{2}$ and $75 \mathrm{CNY} / \mathrm{m}^{2}$ for different systems and collectors. The average cost is $45 \mathrm{CNY} / \mathrm{m}^{2}$. With the soaring housing prices in Chinese cities over the past decade, the incremental cost from SWH systems accounts for only $0.1 \%-0.7 \%$ of the total housing price for different cities. In first-tier cities such as Beijing, Shanghai and Shenzhen, the incremental cost is lower than $0.2 \%$. For developing cities such as Wuhan and Jiangxi, the incremental cost is lower than $0.7 \%$. The average percentage of cost is $0.3 \%$; it is acceptable for developers and residents when considering the energy cost savings from the renewable energy systems.

Although the initial investment of SWH system is higher than that of the other two types of water heaters (electric heating and gas water heaters), its annual actual energy consumption and yearly operating costs are relatively low, and the heating price is lower than that of the other heat sources. In the following section, the economic performance of individual household SWH systems will be analyzed in detail with a case study from Shanghai.

\subsection{Operation and Maintenance}

Insufficient hot water in winter, water leakage, and lack of professional operation and maintenance personnel are the three major problems in the operation of SWH systems. The survey found that only $43 \%$ of solar energy companies conduct operation and maintenance training for property management personnel, and $57 \%$ of solar energy companies do not provide operation and maintenance training.

\section{Case Study}

Sanxiang Haishang Cheng community is located on the south side of Changjiang West Road, Baoshan District, Shanghai. The project consists of seven 18-floor high-rise residential buildings with a height of $52.5 \mathrm{~m} ; 23$ multi-story residential buildings, and several commercial buildings for entertainment and other public uses. The project began construction in March 2010 and was completed in November 2013. Figure 9 shows the layout of the entire community and the location of the high-rise residential buildings.

There are 663 households in the seven high-rise residential buildings, in which, 524 households installed SWH systems. Compound parabolic solar collectors produced by Linuo-Paradigma Co. [63,64] were used in this project. The collectors were mounted on the outside of the apartment balconies with an area of $3 \mathrm{~m}^{2}$. Each household was equipped with a heat storage tank with a volume of $150 \mathrm{~L}$ or $100 \mathrm{~L}$, and a gas boiler as the auxiliary heat source with an output power of $24 \mathrm{~kW}$. The designed solar fraction was $66 \%$ for the household with $150 \mathrm{~L}$ water tank according to the Technical Standard for Solar Water Heating System of Civil Buildings (GB 50364-2018) and the Assessment Code for Performance of Solar Water Heating Systems (GB/T 20095-2006) [65]. The system schematic is shown in Figure 10. The installation node diagrams are shown in Figure 11. Actual photos after the completion of the high-rise building and the SWH system are shown in Figure 12.

To evaluate the economic performance of the individual household SWH systems and compare the performance to EWHs, GWHs, and ASHP water heaters, the levelized cost of heat (LCoH) of different types of water heaters is calculated with Equation (7):

$$
L C o H=\frac{I_{o}-S_{o}+\sum_{t=1}^{T} \frac{C_{t}}{(1+r)^{t}}}{\sum_{t=1}^{T} \frac{E_{t}}{(1+r)^{t}}}
$$


where:

$\mathrm{LCoH}$ is the levelized cost of heat in $\mathrm{CNY} / \mathrm{kWh}$;

$I_{O}$ is the initial investment in CNY;

$S_{O}$ is subsidies and incentives in CNY;

$C_{t}$ is operation and maintenance costs (year $\mathrm{t}$ ) in CNY;

$E_{t}$ is saved final energy (year $\mathrm{t}$ ) in $\mathrm{kWh}$;

$r$ is the discount rate in \%; The discount rate is defined as the weighted average cost of capital (WACC). According to the National Bureau of Statistics of China, 3\% was used in the study. and

$T$ is a period of analysis in the year. 15 was used for solar collectors and ASHPs, and 8 was used for gas boilers in the study.

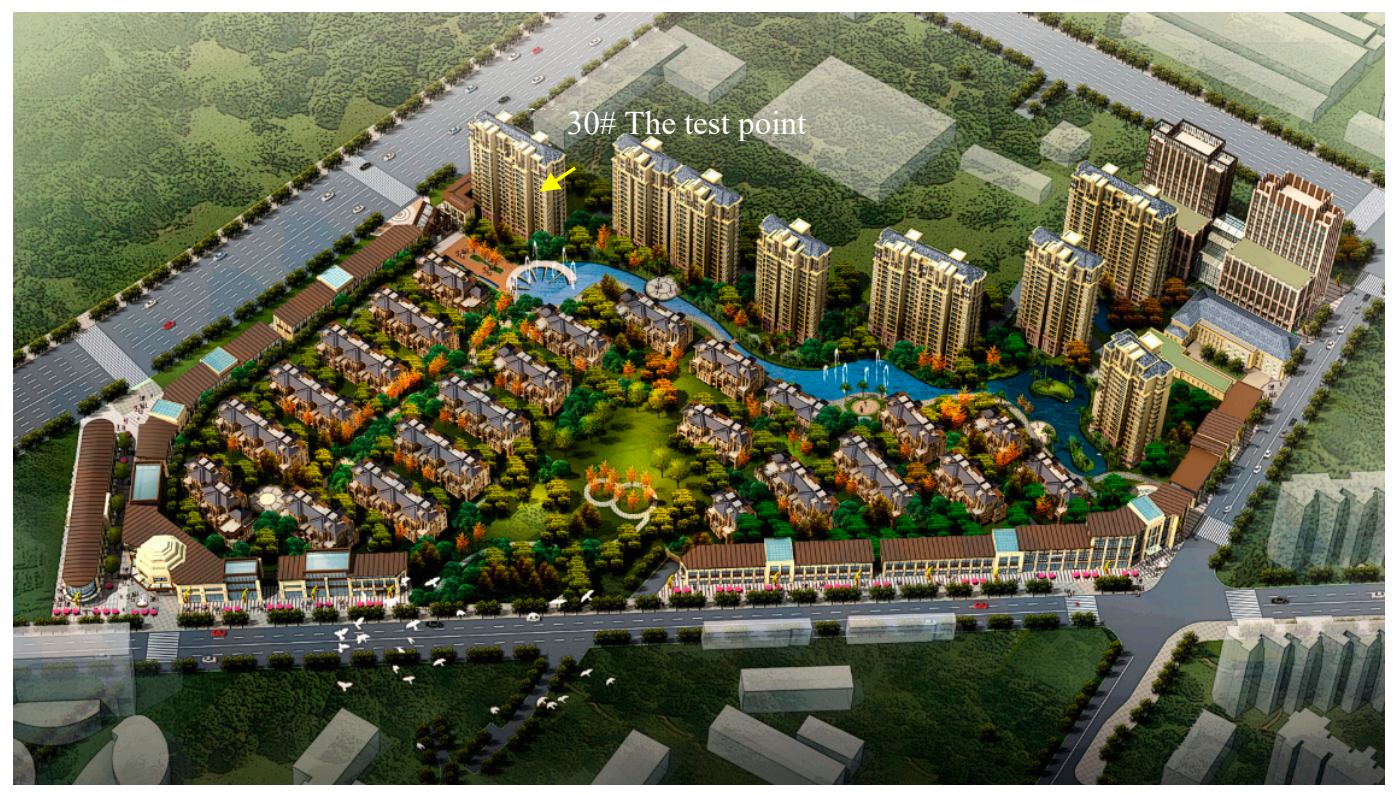

Figure 9. The location of the high-rise residential buildings in Sanxiang Haishang Cheng community.

Pyranometer

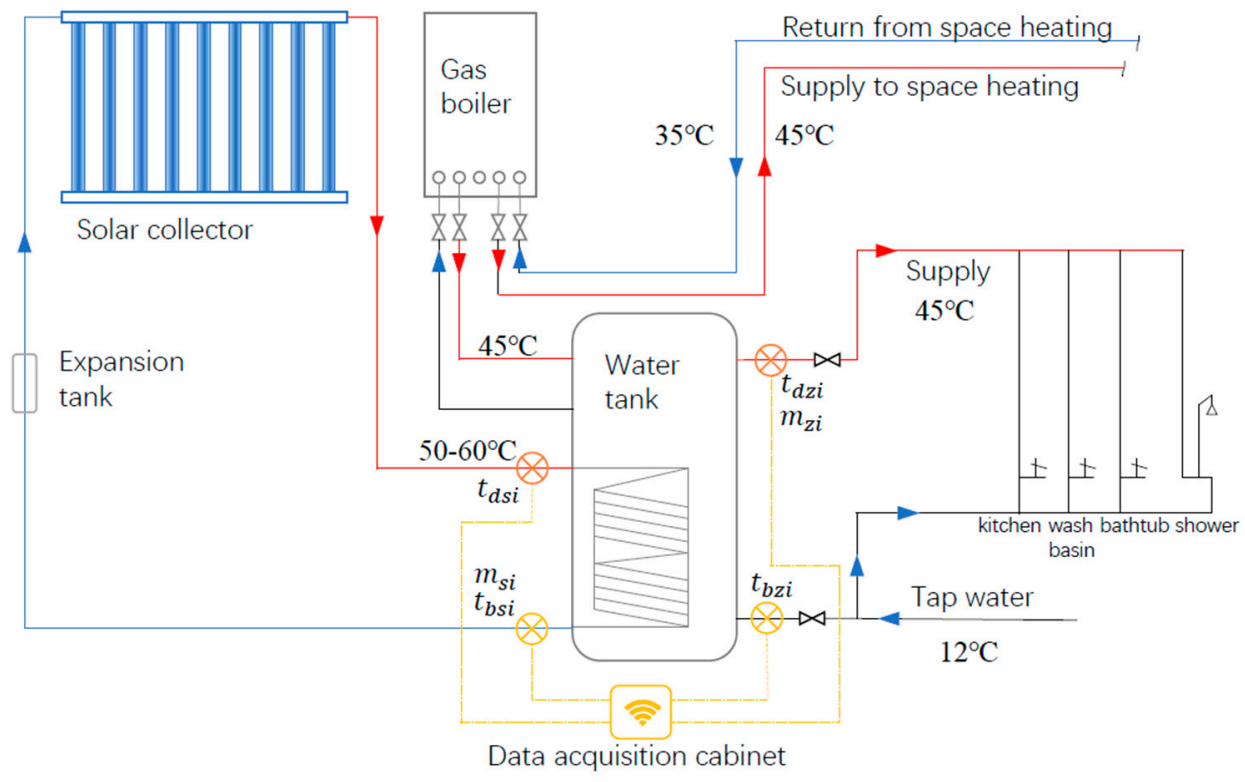

Figure 10. System schematic. 


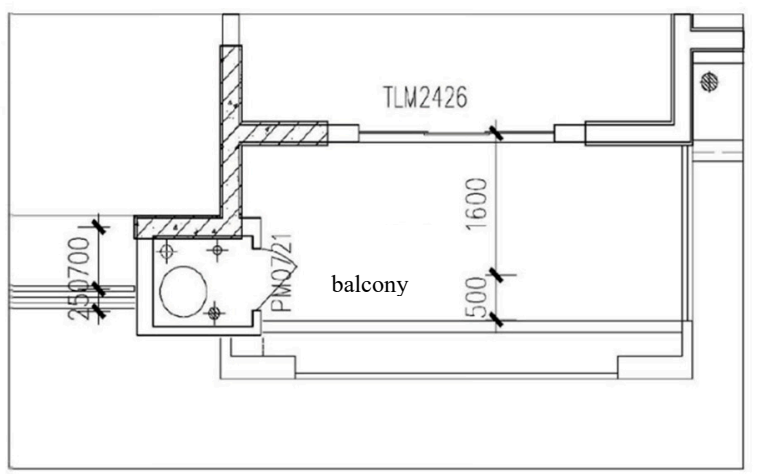

(a) Plan

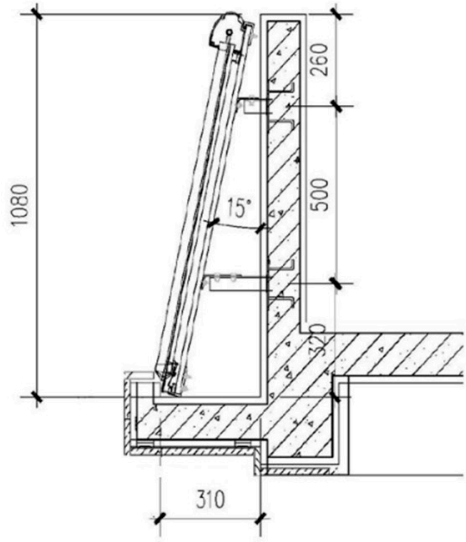

(b) Elevation

Figure 11. The diagram of the installation nodes.

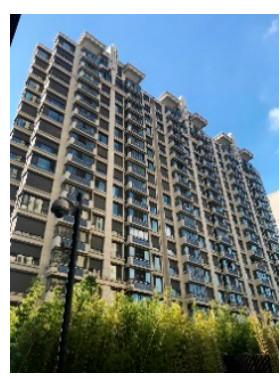

(a) Building elevation

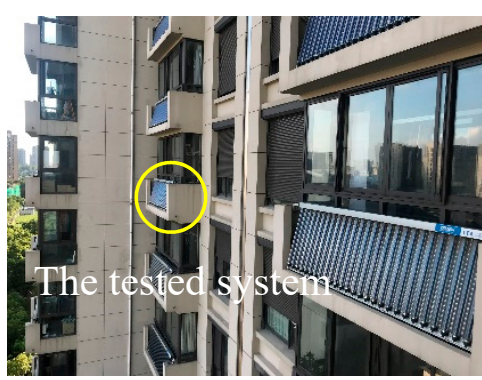

(b) The tested system

Figure 12. Photos after completing the installation.

For the SWH system, the software PolySun is used to calculate the system efficiency, energy savings, and the solar fraction, with the assumptions listed in Table 8.

Table 8. A comparison of the levelized cost of heat ( $\mathrm{LCoH})$ for different water heaters with the SWH system for Shanghai Shanxiang project.

\begin{tabular}{cccccc}
\hline Types & Unit & SWH System & EWH & GWH & ASHP Water Heater \\
\hline Power & $\mathrm{kW}$ & $27^{\mathrm{a}}$ & 2 & 27 & 0.8 \\
\hline Efficiency & $\%$ & $60 \%^{\mathrm{b}}$ & $70 \%$ & $89 \%$ & $\mathrm{COP}, 3.4$ \\
\hline Life span & years & 15 & 8 & 6 & 15 \\
\hline Initial investment & $\mathrm{CNY}$ & $7500+2500$ & 1500 & 2500 & 6000 \\
\hline Subsidies & $\mathrm{CNY}$ & $5400^{\circ}$ & 0 & 0 & 0 \\
\hline Energy price & $\mathrm{CNY} / \mathrm{m}^{3}, \mathrm{CNY} / \mathrm{kWh}$ & $0 / 3.3$ & 0.6 & 3.3 & 0.6 \\
\hline Operation cost & $\mathrm{CNY} / \mathrm{a}$ & 363 & 2190 & 960 & 451 \\
\hline Maintenance cost & $\mathrm{CNY} / \mathrm{a}$ & 300 & 100 & 200 & 200 \\
\hline LCoH & $\mathrm{CNY} / \mathrm{kWh}$ & 0.38 & 0.97 & 0.62 & 0.41
\end{tabular}

${ }^{a}$ Choosing a GWH as the auxiliary heat source. ${ }^{b}$ The efficiency of solar collectors, in this case, choosing CPCs.

${ }^{c}$ There is no subsidy for cities with a mandatory installation policy, but for some cities with incentive policies, such as in Shanghai, there are subsidies from local governments for the installation of SWH systems. In this case, the incremental cost from utilizing SWH systems is $10,000 \mathrm{CNY}$, which accounts for $0.1 \%$ of the house price.

The $\mathrm{LCoH}$ of the SWH system is calculated to be $0.38 \mathrm{CNY} / \mathrm{kWh}$, which is the lowest in comparison to other types of water heaters. The lowest heat price shows the economic advantages of SWH systems in high-rise buildings. 
To verify the system thermal performance and the real contribution from solar collectors, a field measurement was conducted for a typical household located in the middle level of 30\# building $\left(8^{\text {th }}\right.$ floor) as shown in Figures 9 and 12b. The annual solar fraction is calculated with Equation (4). The calculation was summarized in Table 9.

Table 9. The solar fraction (SF) field test and calculation for Shanghai Shanxiang project.

\begin{tabular}{ccccc}
\hline \multirow{2}{*}{ Test Items } & \multicolumn{4}{c}{ Total Solar Radiation on the Day } \\
\cline { 2 - 5 } & $\mathbf{R}<\mathbf{8}$ & $\mathbf{8} \leq \mathbf{R}<\mathbf{1 3}$ & $\mathbf{1 3} \leq \mathbf{R}<\mathbf{1 8}$ & $\mathbf{R} \geq \mathbf{1 8}$ \\
\hline Days $\left(x_{1}, x_{2}, x_{3}, x_{4}\right)$ & 98 & 101 & 77 & 89 \\
\hline SF of the day $\left(S F_{1}, S F_{2}, S F_{3}, S F_{4}\right)$ & $15.5 \%$ & $48.4 \%$ & $72.4 \%$ & $100 \%$ \\
\hline \multicolumn{5}{c}{ The annual $S F_{\text {Annual }}=57.2 \%$} \\
\hline
\end{tabular}

Table 9 shows that there is a difference between the tested annual solar fraction, $57.2 \%$, and the design value of $66 \%$. The difference is mainly due to the shading of the adjacent balcony, as shown in Figure $11 \mathrm{~b}$.

\section{Discussion}

\subsection{Performance Comparison of Different Systems}

Since there is a subsidy for the installation of SWHs in Shanghai, the owners chose the expensive CPCs to take advantage of their higher efficiency and the higher solar fraction. However, this is not a common practice. In high-rise buildings, FPCs are the most commonly used collectors. To compare the economic performance between FPCs and CPCs, the SF and LCoH values with different areas and types of collectors in the Shanghai Sanxiang case are calculated with the PolySun software. The PolySun models are shown in Figure 13 and the input parameters of the models are listed in Table 10.

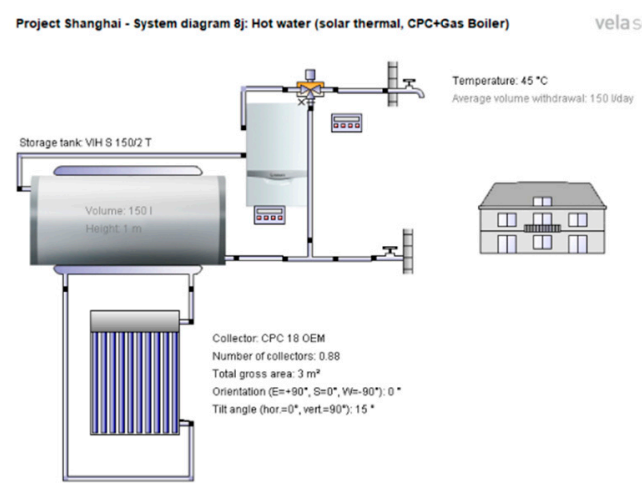

(a) PolySun model for the CPC system

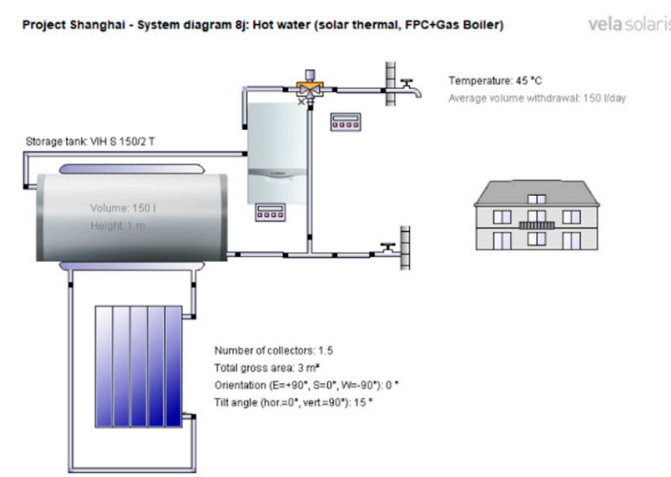

(b) PolySun model for the FPC system

Figure 13. The PolySun model to calculate the solar fraction for CPCs and FPCs. 
Table 10. The input parameters of the PolySun models.

\begin{tabular}{cc}
\hline Location & Shanghai \\
\hline Weather data & Meteonorm weather data \\
\hline Water tank volume & $150 \mathrm{~L}$ \\
\hline The output power of the gas boiler & $24 \mathrm{~kW}$ \\
\hline Supply temperature & $45^{\circ} \mathrm{C}$ \\
\hline Collector area & $3 \mathrm{~m}^{2}$ \\
\hline Collector orientation & South \\
\hline Collector tilt & $15^{\circ}$ \\
\hline
\end{tabular}

Results of the calculations are shown in Figures 14 and 15. Figure 14 shows that the annual SF of the CPC system is higher than that of the FPC system. When the installation area of collectors is $3 \mathrm{~m}^{2}$, the annual SF of the CPC system is 0.67 . For the FPC system, the SF is 0.58 .

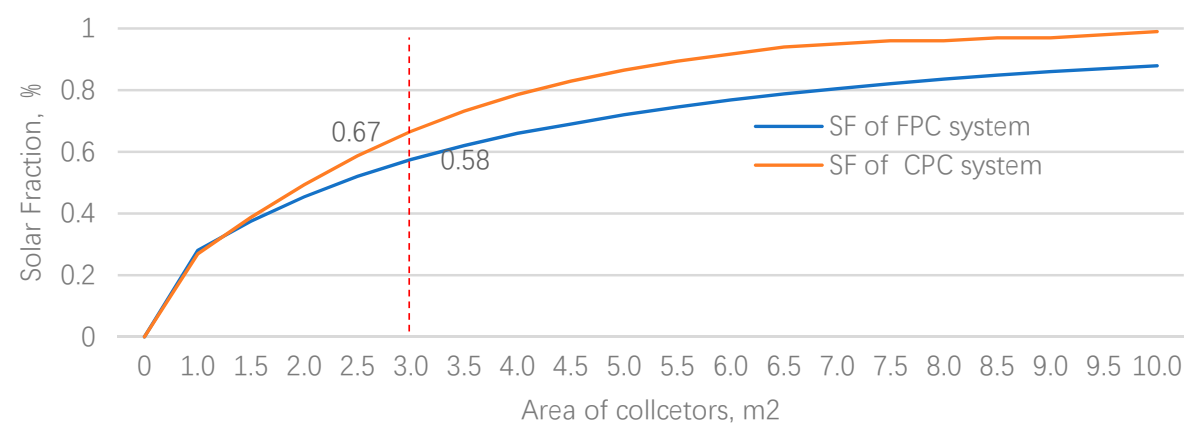

Figure 14. The solar fraction trend with the area $\left(\mathrm{m}^{2}\right)$ of CPC and FPC.

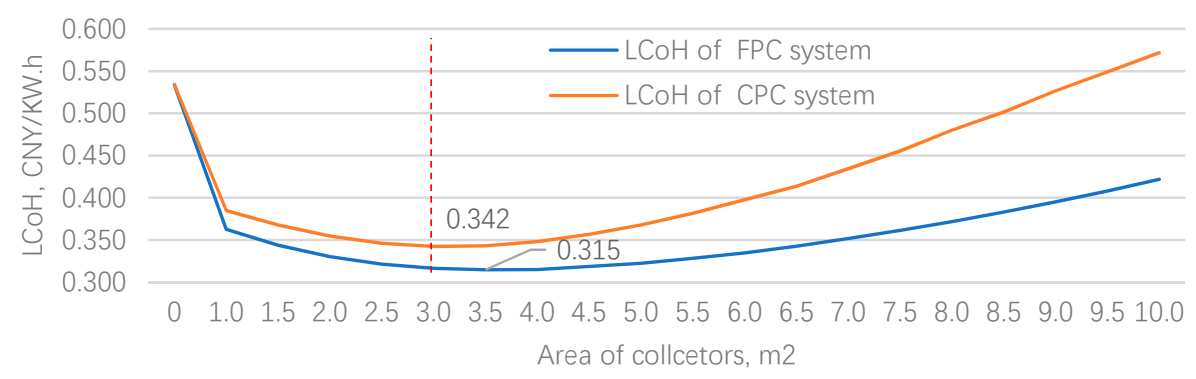

Figure 15. The LCoH curves with the area $\left(\mathrm{m}^{2}\right)$ of collectors with different types of collectors.

Figure 15 shows the economic performance of the two systems. The $\mathrm{LCoH}$ is lowest when the installation area of CPC reaches $3 \mathrm{~m}^{2}$. The lowest $\mathrm{LCoH}$ for the system with FPC is achieved with a collector area of $3.5 \mathrm{~m}^{2}$. Due to the limited space of the balcony, an increase in the collector area is impossible.

The comparison shows that the CPC system can harvest 16\% more solar energy than the FPC system with a corresponding $7 \%$ increase of $\mathrm{LCoH}$ in this case.

Economic performance is also influenced by the auxiliary heat source. The $\mathrm{LCoH}$ curves with electric heating and a gas water heater as the auxiliary heat source for the CPC system are drawn in Figure 16. Figure 16 shows that when the solar collector area is less than $3 \mathrm{~m}^{2}$, the LCoH of electric heating is higher than that of GWH. However, the $\mathrm{LCoH}$ of electric heating would be lower than that of GWH with a larger solar collector area. These calculations validate the rationale for the design in the Shanghai case. 


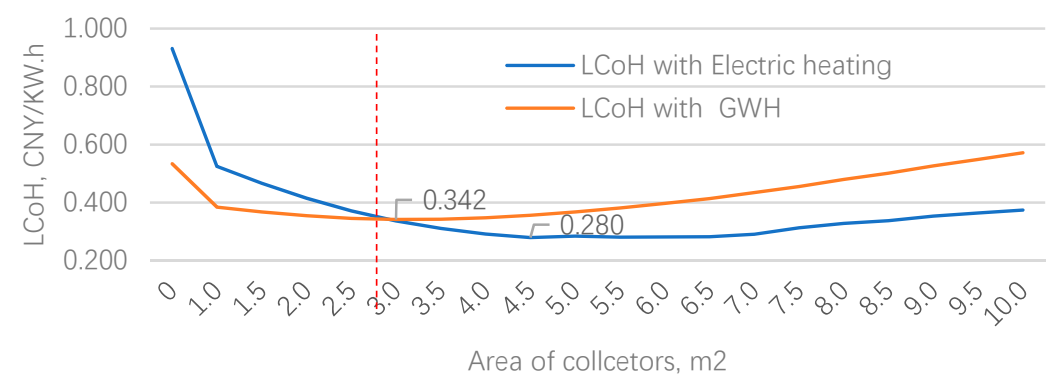

Figure 16. The LCoH curves with the area $\left(\mathrm{m}^{2}\right)$ of collectors with different auxiliary heat sources.

\subsection{Limitations of this Study and Future Work}

This study is based on the technical and economic analysis of China's experience in the application of SWH systems in high-rise buildings. Due to limited time and resources, it is impossible to investigate all SWH systems in high-rise buildings in China, which limits the geographic coverage of the study.

The collectors are limited to the types that have also been widely used. It can be seen from the comparison of various familiar collectors in Table 3 that the listed solar collectors are difficult to integrate with architectural design, due to their large size, considerable weight, and single color (usually black or blue). These factors affect the widespread use of solar heat in high-rise buildings. With the rise of building integrated photovoltaic (BIPV) [66-68] and air source heat pumps in recent years, the application of SWH systems in urban buildings is facing increasing challenges.

However, with technological innovation, there will be more collectors that can easily be integrated into building facades [69], e.g., a PV/T collector that can generate heat and electricity [57], solar thermal air collectors, ceramic solar collectors, polymer solar collectors and solar louvre collectors that can be integrated into curtain walls.

\section{Conclusions}

The experiences and lessons of SWH system applications in high-rise buildings are summarized based on the investigation of 36 existing SWH systems in high-rise buildings in China. The economic performance of SWH systems in high-rise buildings is analyzed and verified by a case study in Shanghai. The following conclusions can be drawn:

1. The installation of SWH systems in high-rise buildings is feasible and reliable with careful design, construction, operation and maintenance. Insufficient hot water in winter $(29 \%)$, water leakage $(21 \%)$, lack of professional operation and maintenance personnel $(10 \%)$ are the three major problems in the operation of SWH systems.

2. Mutual occlusion between buildings will significantly reduce the efficiency of SWH systems. Usually, the aperture area of the collector is half-blocked, and the energy consumption of the auxiliary heat source is correspondingly doubled.

3. An individual household system $(61 \%)$ is better than a centralized system $(25 \%)$ in high-rise buildings in terms of the system efficiency, higher solar fraction for single households, and assurance of the installation area for solar collectors.

4. The average area of solar collectors per household was $2.17 \mathrm{~m}^{2} /$ household, the average design solar fraction was $52 \%$.

5. FPCs are most suitable for the integration with SWH systems in high-rise buildings in terms of system security and reliability. However, when considering the system efficiency, CPCs are better with higher SFs, but the installation of CPC in high-rise buildings requires strict supervision and reliable technical support to ensure safety and security. The system requires fewer CPCs, compared to FPCs, to reach the lowest LCoH.

6. When solar collectors are installed on roofs, a floating board is the best installation method to integrate solar collectors with roofs to ensure adequate installation space and minimize the impact 
on the architectural design. If solar collectors have to be installed on walls, a pallet should be designed to support collectors. Wind loads need to be considered during the structural design of the pallet.

7. Electric heating elements (89\%) were the most common auxiliary heat sources for SWH systems, followed by gas water heaters and air source heat pumps.

8. The cost of SWH systems per $\mathrm{m}^{2}$ of a building area, including the equipment expense and the installation fees, was between $22 \mathrm{CNY} / \mathrm{m}^{2}$ to $75 \mathrm{CNY} / \mathrm{m}^{2}$. The average percentage was $0.3 \%$ of the total building construction cost; it is acceptable for developers and residents when considering the energy cost savings from solar thermal.

Author Contributions: Conceptualization, J.H.; methodology, J.H.; software, J.H.; validation, J.H. and L.L.; formal analysis, J.H. and L.L.; investigation, J.H. and L.L.; resources, J.H.; data curation, J.H. and L.L.; writing-original draft preparation, J.H.; writing-review and editing, J.H.; visualization, J.H.; supervision, J.F. and S.F.; project administration, J.H.; funding acquisition, J.H.

Funding: This research was funded by the International Copper Association Asia, grant number PO18030060. The APC was funded by Technical University of Denmark.

Conflicts of Interest: The authors declare no conflict of interest.

\section{Abbreviations}

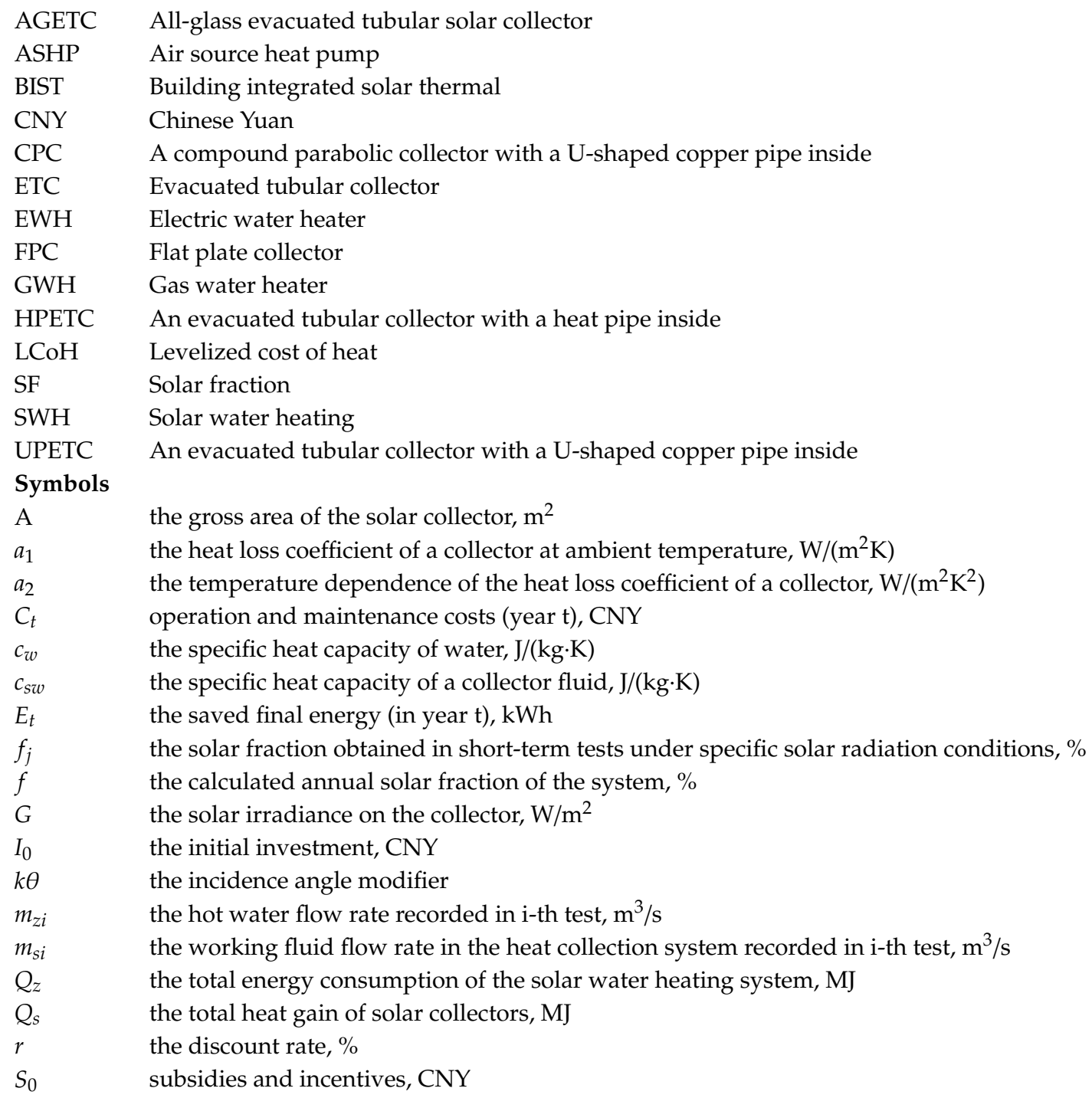


$T \quad$ the period of analysis, year

$t_{d z i} \quad$ the hot water temperature recorded in i-th test, ${ }^{\circ} \mathrm{C}$

$t_{b z i} \quad$ the cold water temperature recorded in i-th test, ${ }^{\circ} \mathrm{C}$

$t_{d s i} \quad$ the collector fluid temperature at the outlet recorded in i-th test, ${ }^{\circ} \mathrm{C}$

$t_{b s i} \quad$ the collector fluid temperature at the inlet recorded in i-th test, ${ }^{\circ} \mathrm{C}$

$\Delta T_{z i} \quad$ the time step, $\mathrm{s}$

$\Delta T_{s i} \quad$ the time step, $\mathrm{s}$

$\eta_{0} \quad$ the peak collector efficiency

$\theta \quad$ the incidence angle for radiation, ${ }^{\circ}$

$\rho_{w} \quad$ the density of hot water, $\mathrm{kg} / \mathrm{m}^{3}$

$\rho_{s w} \quad$ the density of collector fluid, $\mathrm{kg} / \mathrm{m}^{3}$

\section{References}

1. Sawin, J.L.; Rutovitz, J.; Sverrisson, F. Renewables 2018 Gobal Status Report; REN21: Paris, France, 2018.

2. Weiss, W.; Spörk-Dür, M. Solar Heat Worldwide 2018; AEE-Institute for Sustainable Technologies: Gleisdorf, Austria, 2018.

3. Huang, J.; Tian, Z.; Fan, J. A comprehensive analysis on development and transition of the solar thermal market in China with more than 70\% market share worldwide. Energy 2019, 174, 611-624. [CrossRef]

4. Vieira, A.S.; Stewart, R.A.; Lamberts, R.; Beal, C.D. Residential solar water heaters in Brisbane, Australia: Key performance parameters and indicators. Renew. Energy 2018, 116, 120-132. [CrossRef]

5. Benli, H. Potential application of solar water heaters for hot water production in Turkey. Renew. Sustain. Energy Rev. 2016, 54, 99-109. [CrossRef]

6. Bano, F.; Sehgal, V. Evaluation of energy-efficient design strategies: Comparison of the thermal performance of energy-efficient office buildings in composite climate, India. Sol. Energy 2018, 176, 506-519. [CrossRef]

7. Hoffman, L.A.; Ngo, T.T. Affordable solar thermal water heating solution for rural Dominican Republic. Renew. Energy 2018, 115, 1220-1230. [CrossRef]

8. Lee, J.M.; Braham, W.W. Building emergy analysis of Manhattan: Density parameters for high-density and high-rise developments. Ecol. Modell. 2017, 363, 157-171. [CrossRef]

9. Maurer, C.; Cappel, C.; Kuhn, T.E. Progress in building-integrated solar thermal systems. Sol. Energy 2017, 154, 158-186. [CrossRef]

10. Takebayashi, H.; Ishii, E.; Moriyama, M.; Sakaki, A. Study to examine the potential for solar energy utilization based on the relationship between urban morphology and solar radiation gain on building rooftops and wall surfaces. Sol. Energy 2015, 119, 362-369. [CrossRef]

11. Shi, J.; Su, W.; Zhu, M.; Chen, H.; Pan, Y.; Wan, S.; Wang, Y. Solar water heating system integrated design in high-rise apartment in China. Energy Build. 2013, 58, 19-26. [CrossRef]

12. He, G.; Zheng, Y.; Wu, Y.; Cui, Z.; Qian, K. Promotion of building-integrated solar water heaters in urbanized areas in China: Experience, potential, and recommendations. Renew. Sustain. Energy Rev. 2015, 42, 643-656. [CrossRef]

13. Liu, Z.; Liu, Y.; He, B.; Xu, W.; Jin, G.; Zhang, X. Application and suitability analysis of the key technologies in nearly zero energy buildings in China. Renew. Sustain. Energy Rev. 2019, 101, 329-345. [CrossRef]

14. Tsalikis, G.; Martinopoulos, G. Solar energy systems potential for nearly net zero energy residential buildings. Sol. Energy 2015, 115, 743-756. [CrossRef]

15. Raji, B.; Tenpierik, M.J.; Van Den Dobbelsteen, A. An assessment of energy-saving solutions for the envelope design of high-rise buildings in temperate climates: A case study in the Netherlands. Energy Build. 2016, 124, 210-221. [CrossRef]

16. Colmenar-Santos, A.; Vale-Vale, J.; Borge-Diez, D.; Requena-Pérez, R. Solar thermal systems for high rise buildings with high consumption demand: Case study for a 5 star hotel in Sao Paulo, Brazil. Energy Build. 2014, 69, 481-489. [CrossRef]

17. Balter, J.; Ganem, C.; Discoli, C. On high-rise residential buildings in an oasis-city: Thermal and energy assessment of different envelope materiality above and below tree canopy. Energy Build. 2016, 113, 61-73. [CrossRef] 
18. Yoo, J. Evaluation of solar hot water heating system applications to high-rise multi-family housing complex based on three years of system operation. Energy Build. 2015, 101, 54-63. [CrossRef]

19. Pan, W.; Pan, M. A dialectical system framework of zero carbon emission building policy for high-rise high-density cities: Perspectives from Hong Kong. J. Clean. Prod. 2018, 205, 1-13. [CrossRef]

20. Chow, T.T.; Fong, K.F.; Chan, A.L.S.; Lin, Z. Potential application of a centralized solar water-heating system for a high-rise residential building in Hong Kong. Appl. Energy 2006, 83, 42-54. [CrossRef]

21. Wong, L.T.; Mui, K.W.; Guan, Y. Shower water heat recovery in high-rise residential buildings of Hong Kong. Appl. Energy 2010, 87, 703-709. [CrossRef]

22. Lotfabadi, P. High-rise buildings and environmental factors. Renew. Sustain. Energy Rev. 2014, 38, $285-295$. [CrossRef]

23. Sadati, S.; Edwards, R. Incorporating solar energy sources in low energy buildings in two major cities in Iran. Energy Procedia 2019, 156, 85-89. [CrossRef]

24. Alves, T.; Machado, L.; Gonçalves, R.; Souza, D.; De Wilde, P. Assessing the energy saving potential of an existing high-rise office building stock. Energy Build. 2018, 173, 547-561. [CrossRef]

25. Lotfabadi, P. Solar considerations in high-rise buildings. Energy Build. 2015, 89, 183-195. [CrossRef]

26. Thi, P.; Ha, H. A Concept for Energy-Efficient High-Rise Buildings in Hanoi and a Calculation Method for Building Energy Efficiency Factor. Procedia Eng. 2016, 142, 154-160. [CrossRef]

27. Xie, M.; Chenyu, L.; Ying, W.; Wang, J. Comprehensive utilization of renewable energy for new civil buildings in Shanghai. Energy Procedia 1997, 152, 336-341. [CrossRef]

28. Hu, S.; Yan, D.; Guo, S.; Cui, Y.; Dong, B. A survey on energy consumption and energy usage behavior of households and residential building in urban China. Energy Build. 2017, 148, 366-378. [CrossRef]

29. Ahmad, T.; Aibinu, A.; Jamaluddin, M. The effects of high-rise residential construction on sustainability of housing systems. Procedia Eng. 2017, 180, 1695-1704. [CrossRef]

30. Souliotis, M.; Panaras, G.; Fokaides, P.A.; Papaefthimiou, S.; Kalogirou, A.S. Solar water heating for social housing: Energy analysis and Life Cycle Assessment. Energy Build. 2018, 169, 157-171. [CrossRef]

31. Aelenei, L.; Smyth, M.; Platzer, W.; Norton, B.; Kennedy, D.; Kalogirou, S.; Maurer, C. Solar Thermal Systems-Towards a Systematic Characterization of Building Integration. Energy Procedia 2016, 91, 897-906. [CrossRef]

32. Maurer, C.; Cappel, C.; Kuhn, T.E. Simple models for building-integrated solar thermal systems. Energy Build. 2015, 103, 118-123. [CrossRef]

33. O'Hegarty, R.; Kinnane, O.; McCormack, S.J. Review and analysis of solar thermal facades. Sol. Energy 2016, 135, 408-422. [CrossRef]

34. Lamnatou, C.; Mondol, J.D.; Chemisana, D.; Maurer, C. Modelling and simulation of Building-Integrated solar thermal systems: Behaviour of the coupled building/system configuration. Renew. Sustain. Energy Rev. 2015, 48, 178-191. [CrossRef]

35. Zhang, R.; Shen, G.Q.P.; Ni, M.; Wong, J.K.W. Techno-economic feasibility of solar water heating system: Overview and meta-analysis. Sustain. Energy Technol. Assess. 2018, 30, 164-173. [CrossRef]

36. Abd-ur-rehman, M.; Al-sulaiman, F.A.; Mehmood, A. The potential of energy savings and the prospects of cleaner energy production by solar energy integration in the residential buildings of Saudi Arabia. J. Clean. Prod. 2018, 183, 1122-1130. [CrossRef]

37. Hu, R. Research on Mandatory Installation Policy of Solar Water Heater for Civil Buildings. Constr. Sci. Technol. 2008, 61-63. [CrossRef]

38. Hu, R.; Li, J. Global Solar Thermal Industry Incentive Policy and Its Enlightenment to China. Energy China 2007, 29, 27-31.

39. Li, J.; Huang, J. Policies and technical suggestions on the mandatory installation of building integrated solar water heating systems. Hous. Ind. 2010, 7, 20-23. (In Chinese)

40. He, Z. Solar Water Heating Systems Applied in High-rise Residential Buildings in China. Energy Procedia 2016, 91, 408-414. [CrossRef]

41. Hongbing, C.; Xilin, C. Study on the performance of residential centralized solar hot water System. Energy Procedia 2019, 158, 223-228. [CrossRef]

42. Li, D.; Liu, G.; Liao, S. Solar potential in urban residential buildings. Sol. Energy 2015, 111, 225-235. [CrossRef] 
43. Louvet, Y.; Fischer, S.; Furbo, S.; Giovanetti, F.; Mauthner, F.; Mugnier, D.; Philippen, D. Guideline for Levelized Cost of Heat ( $\mathrm{LCOH}$ ) Calculations for Solar Thermal Applications; International Energy Agency: Paris, France, 2017.

44. Munari Probst, M.C.; Roecker, C. Designing solar thermal systems for Architecture integration -criteria and guidelines for product and system developers. In Proceedings of the 3rd IGCP 591 Annual Meeting, Lund, Sweden, 9-19 June 2013.

45. Wall, M.; Cristina, M.; Probst, M.; Roecker, C. Achieving solar energy in architecture—IEA SHC Task 41. Energy Procedia 2012, 30, 1250-1260. [CrossRef]

46. Hachem-vermette, C. Multistory building envelope: Creative design and enhanced performance. Sol. Energy 2018, 159, 710-721. [CrossRef]

47. Sánchez-pantoja, N.; Vidal, R.; Pastor, M.C. Aesthetic impact of solar energy systems. Renew. Sustain. Energy Rev. 2018, 98, 227-238. [CrossRef]

48. Visa, I.; Moldovan, M.; Comsit, M.; Neagoe, M.; Duta, A. Facades integrated solar-thermal collectors-Challenges and solutions. Energy Procedia 2017, 112, 176-185. [CrossRef]

49. Technical Code for Solar Water Heating System of Civil Buildings (GB 50364-2005); China Building Industry Press: Beijing, China, 2005.

50. Luo, S.; Li, H.; Mao, Y.; Yang, C. Experimental research on a novel sun shading \& solar energy collecting coupling device for inpatient building in hot summer and cold winter climate zone in China. Appl. Therm. Eng. 2018, 142, 89-99. [CrossRef]

51. Lu, S. Study of Solar Water Heating System Integrated with High-rise Building for the Large Scale Application; Tianjin University: Tianjin, China, 2008.

52. Zhong, J.; Zhang, L. A Study on Application of Solar Water Heating System in High-rise Apartments. Hous. Sci. 2009, 6-11. [CrossRef]

53. Peng, C.; Hao, B. From Solar Energy to Solar Can, Efficiency and Design of Solar Water Heating System, 1st ed.; China Building Industry Press: Beijing, China, 2018.

54. Ministry of Housing and Urban-Rural Development of the People's Republic of China. Code for Design of Building Water Supply and Drainage (GB50015-2003), 2nd ed.; China Planning Press: Beijing, China, 2009.

55. QU, Y. Research on Application of Solar Hot Water System Technology for Residential Buildings in Shanghai. Archit. Technol. 2012, 43, 1-4.

56. Kalogirou, S.A.; Kalogirou, S.A. Performance of Solar Collectors. Sol. Energy Eng. 2014, 221-256. [CrossRef]

57. Buker, M.S.; Riffat, S.B. Building integrated solar thermal collectors-A review. Renew. Sustain. Energy Rev. 2015, 51. [CrossRef]

58. Horta, P.; Brunner, C.; Kramer, K.; Frank, E. IEA/SHC T49 Activities on Process Heat Collectors: Available Technologies, Technical-Economic Comparison Tools, Operation and Standardization Recommendations. Energy Procedia 2016, 91, 630-637. [CrossRef]

59. Visa, I.; Duta, A. Innovative Solutions for Solar Thermal Systems Implemented in Buildings. Energy Procedia 2016, 85, 594-602. [CrossRef]

60. Visa, I.; Comsit, M.; Duta, A. Urban acceptance of facade integrated novel solar thermal collectors. Energy Procedia 2014, 48, 1429-1435. [CrossRef]

61. Jie, S.; Dexuan, S.; Huaning, C.; Wei, S. Reseach on intergreted design solar energy with high-rise apartement in Shanghai. Archit. J. 2009, 10, 11-15. (In Chinese)

62. Liu, J. Comparative study on performance of different auxiliary heating modes for separated solar water heating system. Water Supply Sewerage 2017, 43, 6. [CrossRef]

63. Wan, S. Discussion on the Selection of Solar Hot Water System Types in High-rise Residential Buildings. Water Wastewater Eng. 2009, 65-69. [CrossRef]

64. Yan, F.; Ma, G.; Xia, L. Study on Integration of Veranda Fence Solar Heat Collector with Building. Archit. Technol. 2017, 48, 3.

65. China National Standardization Administration. Assessment Code for Performance of Solar Water Heating Systems (GB/T 20095-2006); China Standard Press: Beijing, China, 2006.

66. Huide, F.; Xuxin, Z.; Lei, M.; Tao, Z.; Qixing, W.; Hongyuan, S. A comparative study on three types of solar utilization technologies for buildings: Photovoltaic, solar thermal and hybrid photovoltaic/thermal systems. Energy Convers. Manag. 2017, 140, 1-13. [CrossRef] 
67. Kosori, V.; Lau, S.; Tablada, A.; Lau, S.S. General model of Photovoltaic (PV) integration into existing public high-rise residential buildings in Singapore-Challenges and benefits. Renew. Sustain. Energy Rev. 2018, 91, 70-89. [CrossRef]

68. Wang, Y.; Lin, H.; Liu, L.; Wennersten, R.; Sun, Q. High-rise building peak load shaving using rooftop attached PV. Energy Procedia 2018, 152, 484-489. [CrossRef]

69. Harmim, A.; Boukar, M.; Amar, M.; Haida, A. Simulation and experimentation of an integrated collector storage solar water heater designed for integration into building facade. Energy 2019, 166, 59-71. [CrossRef]

(C) 2019 by the authors. Licensee MDPI, Basel, Switzerland. This article is an open access article distributed under the terms and conditions of the Creative Commons Attribution (CC BY) license (http://creativecommons.org/licenses/by/4.0/). 